\title{
Brian Leiter
}

\section{Dlaczego tolerować religię? \\ Why Tolerate Religion?}

Poniższy tekst jest przekładem wprowadzenia i rozdziału I książki Briana Leitera Why Tolerate Religion? Copyright (C) 2013 by Princeton University Press. Przekład i przedruk za zgodą Wydawnictwa.

\section{Streszczenie}

Większość systemów prawnych zachodnich demokracji zawiera uregulowania przyznające specjalne przywileje religiom, w szczególności zaś zwolnienia z niektórych powszechnie obowiązujących praw, jeśli te wchodzą w konflikt z przeświadczeniami religijnymi. Tak daleko idącą tolerancją ze strony państwa zwykle nie cieszą się inne, podobnie silnie żywione przekonania. Artykuł stawia pytanie, jak można uzasadnić tego rodzaju uprzywilejowanie poglądów religijnych. Argumenty niektórych filozofów (np. Thomasa Hobbesa) - sugerujące zwykłą nieopłacalność postawy nietolerancyjnej - mają charakter instrumentalny i w żaden sposób nie dowodzą, iż tolerancja miałaby być cnotą moralną. Wynika to dopiero z argumentów Johna Stuarta Milla i Johna Rawlsa, egzemplifikujących, odpowiednio, utylitaryzm i deontologię. Żaden z analizowanych argumentów na rzecz wolności sumienia i wyznania nie odróżnia pomiędzy przeświadczeniami religijnymi i innymi, co sugeruje, że istniejące różnice w ich moralnym i prawnym traktowaniu nie znajdują uzasadnienia. Powstaje zatem pytanie, czy uregulowania prawne wobec przeświadczeń religijnych i innych nie powinny zostać zrównane, tak aby poglądy religijne nie były uprzywilejowane.

Słowa kluczowe: tolerancja, religia, wolność wyznania i sumienia, argumenty na rzecz tolerancji, John Stuart Mill, John Rawls 


\section{Summary}

The majority of legal systems in Western democracies accord special treatment to religions, e.g. exemptions from generally applicable laws if they conflict with religious convictions. Other beliefs do not usually enjoy such far-reaching tolerance on the part of the state. The article raises the question of how granting such privilege to religious views can be justified. Arguments of some philosophers (e.g. Thomas Hobbes') which suggest that an intolerant attitude might sometimes be disadvantageous are in fact only instrumental, and do not prove that tolerance is a moral virtue. This last claim only follows from the arguments of John Stuart Mill and John Rawls, who exemplify two basic approaches in ethics, i.e. utilitarianism and deontology. None of the analyzed arguments for freedom of conscience and religion distinguishes between religious and other beliefs, which suggests that the existing differences in their moral and legal treatment cannot be justified. Therefore, the question arises of whether legal regulations regarding religious and other beliefs should not be equated, so that religious views are not privileged.

Keywords: toleration, religion, freedom of conscience and religion, arguments for toleration, John Stuart Mill, John Rawls

\section{Wrowadzenie}

Czternastoletni chłopiec pierwszego dnia roku szkolnego wkracza do klasy w swoim nowym gimnazjum mając przy sobie, jak zwykle, swój sztylet. Zaniepokojona nauczycielka powiadamia dyrektora, który dzwoni na policję: noszenie broni w szkole jest, rzecz jasna, zabronione, toteż policjanci niezwłocznie konfiskują sztylet chłopca.

Przypadek być może oczywisty, ale nie wtedy, gdy wspomniany chłopiec jest gorliwym sikhem. W religii sikhów bowiem męski wyznawca musi nosić ze sobą kirpan - sztylet lub miecz - jako symbol religijnego oddania. W obrębie wielu systemów prawnych, zarówno w Ameryce Północnej jak 
i w Europie, sikhowie stają przed koniecznością kwestionowania praw zakazujących wnoszenia broni do szkoły, jako że te uniemożliwiają im spełnianie ich religijnych zobowiązań. I w wielu przypadkach przyznano im przywilej nieprzestrzegania tych praw, na mocy argumentu, że wolność wyznania wymaga, by państwo tolerowało pewne wyjątki od ogólnych zakazów. Uważa się, że nakaz sumienia pobożnego sikha do noszenia kirpanu jest zbyt poważny - zbyt istotny dla integralności i tożsamości wierzącego - by wymagać, aby z niego zrezygnował z powodu ogólnego zakazu noszenia broni, za którą wszyscy inni uznaliby kirpan, stwarzający zagrożenie dla bezpieczeństwa szkoły.

Jednak przypuśćmy teraz, że nasz czternastoletni chłopiec nie jest sikhem, lecz pochodzi z wiejskiej rodziny, której tradycje sięgają wiele pokoleń wstecz. Jak w niemal każdej kulturze, w społeczności tego chłopca obecne są rytuały wyznaczające osiągnięcie dojrzałości należących do niej mężczyzn. Kluczowym z nich jest przekazywanie sztyletu bądź noża z ojca na syna, z pokolenia na pokolenie. Być „mężczyzną" w wieku trzynastu czy czternastu lat znaczy otrzymać taki sztylet od ojca, jak i on otrzymał go od swojego, i tak dalej, na przestrzeni dziesiątek, a może i setek lat. Tożsamość chłopca jako mężczyzny w jego społeczności zależy od tego, czy będzie zawsze nosił przy sobie rodzinny nóż, będący symbolem jego dojrzałości i więzi z przeszłością. Nie może być żadnych wątpliwości co do nakazu sumienia, jaki każdy chłopiec w tym wieku odczuwa, a który nakazuje mu nosić swój nóż ze sobą, nawet w szkole. I nie może być żadnych wątpliwości, że gdyby odebrano mu możliwość noszenia tego noża, jego tożsamość jako oddanego członka swojej społeczności zostałaby zniszczona.

Nie istnieje obecnie w zachodnim świecie żadne demokratyczne państwo, w którym chłopiec z naszego drugiego scenariusza podważył lub mógłby skutecznie podważyć ogólny zakaz wnoszenia broni na teren szkoły. Gdyby był sikhem, miałby 
na to spore szanse. Jeżeli jednak może odwołać się jedynie do wielowiekowej tradycji, która jest kluczowa dla jego tożsamości i z którą czuje się nierozerwalnie związany przez obyczaje rodzinne i swoje wychowanie, ma niestety pecha. Kluczowe pytanie tej książki brzmi: dlaczego państwo powinno tolerować wyjątki od ogólnie obowiązujących praw, gdy te wchodzą w konflikt ze zobowiązaniami religijny mi, lecz nie wtedy, gdy są sprzeczne z jakimikolwiek innymi, równie ważnymi nakazami sumienia?

Rozpocznę od przyjęcia, że moralny ideał tolerancji - „znoszenia" praktyk, których się nie aprobuje, ponieważ jest to moralnie słuszne - stanowi najlepsze uzasadnienie dla naszej zachodniej koncepcji wolności wyznania. Zaprezentuję kilka znanych (przynajmniej etykom i filozofom politycznym) argumentów na rzecz tej idei. Następnie zadam pytanie, czy istnieje jakikolwiek powód, by sądzić, że ten ideał moralny dotyczy jedynie religijnych nakazów sumienia, chroniąc naszego młodego sikha, lecz pozostawiając chłopca z wioski bez żadnego prawnego remedium. Wymaga to wyjaśnienia, co wyróżnia religijne roszczenia sumienia; jest to temat rozdziału drugiego. Następnie, w rozdziale trzecim, pokazuję, że najlepsze argumenty na rzecz tolerancji nie wskazują wyłącznie na religię, rozumianą tak jak w rozdziale drugim, jako godna specjalnych zwolnień z powszechnie obowiązujących praw.

W rozdziale czwartym rozważam ewentualność, że punkt wyjścia całej analizy był błędny: być może u podstaw wolności wyznania leży wzór moralny nie tolerancji, lecz bardziej wymagającej koncepcji s z a cu n ku wobec religii. Przytaczam różne możliwe sposoby rozumienia tego bardziej wymagającego ideału i dochodzę do wniosku, iż nie ma powodu by sądzić, że religijne nakazy sumienia na niego zasługują.

W końcu, w rozdziale piątym, rozważam, co począć w kwestii naszego sikha oraz chłopca z tradycyjnej wioski, skoro faktycznie nie ma żadnego powodu, by wyłącznie w przypadku tego pierwszego respektować nakazy sumienia domagające się 
noszenia broni w miejscach, w których jest to normalnie zabronione. Staram się wykazać, że „pecha” powinni mieć obaj chłopcy: że nie powinno się robić wyjątków od powszechnych praw mających neutralne cele, chyba, że wyjątki te nie obciążają i nie narażają innych. Rozważam również, czy moralny ideał tolerancji, który opisuję i którego bronię w tej książce, jest niezgodny z obowiązywaniem religii państwowej (wyznaniowością państwa), a z drugiej strony z rozdziałem kościoła od państwa. Próbuje dowieść, że nie jest sprzeczny ani z jednym, ani z drugim i że tolerancyjne państwo mogłoby być, co do zasady, zarówno religijne, jak i antyreligijne*.

\section{Rozdziat I. Tolerancja}

Tolerancja religijna od dawna stanowi paradygmat liberalnego ideału tolerancji różnic międzygrupowych, co widać zarówno w konstytucjach czołowych zachodnich demokracji, jak i w literaturze teoretycznej wyjaśniającej i uzasadniającej te praktyki. Konstytucja Stanów Zjednoczonych stanowi, że „Żadna ustawa Kongresu nie może ustanawiać religii ani zabronić swobodnego jej praktykowania"1. Jak zapewnia Konstytucja (Ustawa

* Przypis redakcji: Argumentacja autora, że państwo wyznaniowe, w którym obowiązuje religia państwowa, może być mimo wszystko tolerancyjne, opiera się na przykładzie Wielkiej Brytanii: „Chrześcijaństwo anglikańskie jest "oficjalną" religią Wielkiej Brytanii - jest dosłownie »Kościołem Anglii - a to oznacza, że modlitwy i liturgie anglikańskie są zwyczajowymi elementami życia publicznego i przynajmniej rodzina królewska ciągle jeszcze deklaruje lojalność wobec Kościoła" (B. Leiter, Why Tolerate Religion?, s. 120). Jednocześnie: „nie ma kryteriów religijnych przy obsadzaniu urzędów publicznych; szkoły religijne o tradycjach nieanglikańskich w istocie otrzymują fundusze publiczne; innym tradycjom religijnym gwarantuje się prawo do praktykowania swoich religii; (...) w końcu, jak lubią zauważać moi angielscy przyjaciele, nie jest nawet do końca jasne, czy arcybiskup Canterbury w ogóle wierzy w Boga" (tamże).

${ }^{1}$ Poprawka I do Konstytucji Stanów Zjednoczonych Ameryki, przeł. A. Pułło, Wydawnictwo Sejmowe, Warszawa 2002 (przekład nieznacznie zmieniony). Dalsza część przypisu została pominięta ze względu na jej 
Zasadnicza) Niemiec w artykule 4: „Wolność wyznania, sumienia, przekonań religijnych i światopoglądowych jest nienaruszalna”, dodając w osobnej klauzuli, że „Zapewnia się swobodę praktyk religijnych”2. Pierwszą z czterech „Podstawowych wolności” Kanadyjskiej Karty Praw i Wolności jest „wolność sumienia i religii”", natomiast artykuł 18 Powszechnej Deklaracji Praw Człowieka stwierdza:

Każdy człowiek ma prawo wolności myśli, sumienia i wyznania; prawo to obejmuje swobodę zmiany religii lub wyznania oraz swobodę głoszenia swej religii lub wyznania indywidualnie, bądź wespół z innymi ludźmi, publicznie i prywatnie, poprzez nauczanie, praktykowanie, uprawianie kultu i przestrzeganie obyczajów ${ }^{4}$.

Podczas gdy konstytucja Stanów Zjednoczonych wymienia jedynie religię ${ }^{5}$, uznanie roszczeń „sumienia” w innych aktach

techniczno-prawny charakter, uwikłanie w specyficzne realia polityczno-prawne USA i niewielką rolę, jaką pełni w całości tekstu.

${ }^{2}$ Konstytucja Niemiec, przeł. B. Banaszak i A. Malicka, Wydawnictwo Sejmowe, Warszawa 2008, art. 4 (1)-(2).

${ }^{3}$ Kanadyjska Karta Praw $i$ Wolności, w: Konstytucja Kanady, przeł. J. Osiński i I. Zawiślińska, Wydawnictwo Sejmowe, Warszawa 1998, § 2 (Podstawowe wolności).

${ }^{4}$ Powszechna Deklaracja Praw Człowieka, rezolucja Zgromadzenia Ogólnego ONZ 217, 10.12.1948, art. 18.

${ }^{5}$ Niektóre z rozstrzygnięć Sądu Najwyższego Stanów Zjednoczonych w sprawach kwestionujących Ustawę o Powszechnym Szkoleniu Wojskowym i Stuzbie Wojskowej (Universal Military Training and Service Act), miały tendencję (przynajmniej wtedy, gdy dotyczyły osób odmawiających służby wojskowej ze względu na swoje przekonania) do poszerzania definicji „religii” tak, aby objąć szerszy zakres nakazów sumienia. Por. zwłaszcza sprawy: United States v. Seeger („United States Reports” t. 380, 1965, s. 163-193) i Welsh v. United States („United States Reports” t. 398,1970 , s. 333-374). Jednakże nawet te przypadki rozstrzygane były na poziomie interpretacji prawa, a nie zasad konstytucyjnych. José Louis Martí zwrócił moją uwagę na to, że sądy w Hiszpanii doszły do podobnych wniosków na temat odmowy służby wojskowej ze względu na przekonania. W podobnym duchu Europejska Komisja Praw Człowieka w sprawie Arrowsmith v. United Kingdom („European Human Rights Reports” t. 3, 
prawnych jest raczej powierzchowne niż istotne: rozstrzygane sądownie spory w przytłaczającej większości odnoszą się do nakazów sumienia religijnego ${ }^{6}$. W istocie, gdyby nie takie właśnie

1978, s. 218-245) rozważała, czy Artykuł 9 Europejskiej Konwencji Praw Człowieka („Council of Europe Treaty Series” 5, 1953), zapewniajacy wolność sumienia i religii, chroni niereligijnych pacyfistów przed kara za rozpowszechnianie wśród brytyjskich żołnierzy pism zachęcających do powstrzymania się od udziału w walkach w Irlandii Północnej. Komisja uznała, że choć „pacyfizm jako filozofia (...) podpada pod zakres wolności myśli i sumienia" (Arrowsmith..., s. 228), to pisma, o których mowa, nie miały tak naprawdę charakteru pacyfistycznego, zatem nałożenie kar za ich rozpowszechnianie nie naruszało Artykułu 9 (tamże, s. 230).

6 Douglas Laycock zauważa w Regulatory Exemptions of Religious Behavior and the Original Understanding of the Establishment Clause („Notre Dame Law Review” 81, 2006, s. 1839), że „zdecydowana większość osób odmawiających służby wojskowej ze względu na wymogi sumienia (...) jest religijna w tradycyjnym sensie”. Istotna większość takich spraw, które były rozpatrywane przez Europejski Trybunał Praw Człowieka także dotyczyła wyznawców jakiejś religii (w przeciwieństwie do tych, którzy swoją odmowę opierają na świeckich bądź pacyfistycznych podstawach).

Mój asystent naukowy, John Wasserman, przejrzał setki amerykańskich spraw sądowych wytoczonych przez ateistów i agnostyków i żadna z nich nie kwestionowała „neutralnego prawa o powszechnej stosowalności”, jak napisał sędzia Antonin Scalia w uzasadnieniu większościowej opinii sądu w sprawie Employment Division, Department of Human Resources of Oregon v. Smith („United States Reports” t. 494, 1990, s. 872 i 880). Zarówno przed jak i po sprawie Smitha powodowie o ateistycznym lub agnostycznym światopoglądzie zwracali uwagę, że państwo łamie prawo do swobody praktyk religijnych łą c z nie z prawem o rozdziale kościoła od państwa bądź inną ustawą zabraniającą uprzywilejowania jednego wyznania nad inne (bądź nad żadne). Por. np. sprawę: Friedman v. Board of County Commissioners of Bernalillo County („Federal Reporter, 2nd Series" t. 781, 1985, s. 777-791): powód - ateista - argumentowal, że pieczęć hrabstwa zawierająca krzyż oraz motto „Oto Nasz Oręż” narusza prawo do swobodnego praktykowania religii i rozdziału kościoła od państwa. Zatem roszczenia powodów o ateistycznym bądź agnostycznym światopoglądzie nie opierały się na twierdzeniu, jakoby prawa mające oddawać ogólną, neutralną w sprawie religii politykę państwa w jakiś sposób kolidowały z ich religijnymi (czy raczej należałoby powiedzieć - niereligijnymi) praktykami; wynikały raczej z osądu, że prawa te wcale nie sa neutralne, a miast tego faworyzują religię bądź jakieś konkretne wyznanie dyskryminując ateizm czy agnostycyzm. Por. np. sprawę: Nicholson 
nakazy były podstawowym problemem, to z pewnością wskazywanie explicite na religię (lub mowa o jej specjalnej ochronie) wydawałoby się zbędne w kontekście ochrony przyznawanej rzekomo wszelkim roszczeniom sumienia.

O ile historyczne powody przyznania honorowego miejsca tolerancji religijnej są znane ${ }^{7}$, bardziej zastanawiające jest to,

v. Board of Commissioners of the Alabama State Bar Association, ("Federal Supplement" t. 338, 1972, s. 48-58), w której powód - prawnik ateista - podważał wymóg stanowej izby adwokackiej, aby nowy jej członek składał przysięgę odwołującą się do Boga. W najlepszym razie istnieje ledwie kilka (niejednoznacznych) spraw, w których niereligijni powodowie domagali się utworzenia wyjątku od powszechnie obowiązującej zasady przez wzgląd na wymogi swego sumienia. Dla przykładu sprawa Wells v. City and County of Denver („Federal Reporter, 3rd Series” t. 257, 2001, s. 1132-1157) została wniesiona przez grupę ateistów, którzy chcieli wystawić symbol przesilenia zimowego w obszarze objętym zakazem wystawiania prywatnych ekspozycji. Lokalne władze utworzyły w tym miejscu świąteczną wystawę zawierającą symbolikę różnych religii; można argumentować, że roszczenie wysunięte przez powodów należy uznać za oparte na twierdzeniu, jakoby zakaz umieszczania prywatnych ekspozycji w ty m miejscu naruszał ich prawo do swobodnego praktykowania religii. Bardziej jednak wiarygodnie można twierdzić, że grupa kwestionowała religijną neutralność wystawy zawierającej symbolikę judeochrześcijańską - a zatem sprawa odnosiła się raczej do kwestii rozdziału kościoła od państwa, jedynie z powołaniem się na prawo swobodnego praktykowania religii. W związku z tym sąd odrzucił powództwo z tytułu prawa do swobodnego praktykowania religii, określając je jako „trudno uchwytne” (tamże, s. 1152).

Podsumowując, choć w kilku przypadkach można argumentować, że ateiści lub agnostycy starali się podważyć neutralne, powszechnie obowiązujące prawo, ponieważ obciążało ono ich „praktykę religijną”, wydaje się, że nie ma na to całkowicie jednoznacznego przykładu. Przeważnie, jeżeli nie wyłącznie, powództwa wystosowywane przez ateistów i agnostyków dotyczące ustaw bądź działań rządu wskazują na ich religijne motywacje, a nie na neutralne motywacje, które mimo wszystko w sposób niezgodny z konstytucją obciążają ateistów i agnostyków. Por. np. sprawę Freedom From Religion Foundation v. Hanover School District („Federal Reporter, 3rd Series” t. 626, 2010, s. 1-15), w której kwestionowano użycie słów „pod władaniem Boga” w tekście Przysięgi Wierności.

7 Por. np. opinię Douglasa Laycocka na temat doświadczeń, które ukonstytuowały Amerykę: „(...) w okresie, który dla założycieli Stanów 
że nikt nie sformułował jak dotąd wiarygodnego pryncypi al n e go argumentu na rzecz tolerowania religii jako religii - tj. argumentu, który wyjaśniałby, dlaczego mamy moralna powinność, aby specjalnie traktować praktyki religijne pod względem prawnym i etycznym. Oczywiście istnieją istotne argumenty na rzecz tolerowania przez państwo całej gamy prywatnych wyborów i zobowiązań sumienia, jak i powiązanych z nimi praktyk jego obywateli, jednak żaden z tych argumentów nie wskazuje religii jako zasługującej na specjalne traktowanie, którym cieszy się ona obecnie w zachodnich systemach prawnych. Dlaczego więc mamy tolerować religię? Odpowiedź proponowana w tej książce brzmi: nie ze względu na cokolwiek, co dotyczy religii jako takiej - a przynajmniej tego postaram się dowieść.

\section{Tolerancja pryncypialna*}

By zrozumieć, dlaczego tak jest, musimy zacząć od poczynienia pewnych rozróżnień, które umożliwią nam sformułowanie tego pytania w bardziej przejrzysty sposób. W szczególności, musimy jasno określić, co jest sednem tzw. z a s ady tolerancji (principle of toleration). Jako punkt wyjścia przyjmę użyteczne sformułowanie tego problemu au-

Zjednoczonych był historią najnowszą, rządowe próby tłumienia niepożądanych poglądów religijnych doprowadziły do ogromu ludzkich cierpień w Anglii i w całej Europie, a także, choć w nieco mniejszej skali, w koloniach, które miały stać się Stanami Zjednoczonymi" (Religious Liberty as Liberty, „Journal of Contemporary Legal Issues” 7, 1996, s. 317).

* Przypis tłumaczy: Angielski termin brzmi Principled toleration. $\mathrm{Z}$ tekstu wynika jednoznacznie, że określeniem, które klarownie oddawałoby jego sens jest „tolerancja oparta na zasadach moralnych (moral principles)". Określenie takie jest naturalnie zbyt nieporęczne, aby je wielokrotnie powtarzać $\mathrm{w}$ tekście. W takim właśnie sensie będzie więc używane określenie „tolerancja pryncypialna”, które powinno być rozumiane jako rodzaj terminu technicznego. 
torstwa niedawno zmarłego angielskiego filozofa Bernarda Williamsa:

Praktykowanie tolerancji oznacza jedynie, że pewna grupa faktycznie znosi istnienie innej, odmiennej grupy. (...) Jedną z możliwych podstaw takiego zachowania (...) jest cnota tolerancji podkreślająca moralne dobro leżące w znoszeniu przekonań, które ocenia się negatywnie. (...) Aby można było mówić o tolerancji, niezbędne jest, by istniało pewne przekonanie, praktyka bądź sposób życia, który pewna grupa uważa (jakkolwiek fanatycznie czy bezzasadnie) za zły, błędny lub niepożądany ${ }^{8}$.

Aby można było mówić o p rakty k o w a niu tolerancji, jedna grupa musi uznawać przekonania bądź sposoby zachowania innej za „złe, błędne lub niepożądane”, a jednak „znosić” je mimo to. A zatem nie można mówić o tolerancji w sytuacji, gdy danej grupie inna jest po prostu obojętna. Nie „toleruję" moich homoseksualnych czy mających odmienny kolor skóry sąsiadów, ponieważ odcień skóry bądź orientacja seksualna osób w moim otoczeniu są mi obojętne. Tolerancja jako ideał moralny może mieć znaczenie wyłącznie wtedy, gdy jedna grupa jest ż y w o zainteresowana tym, co członkowie drugiej czynią, w co wierzą lub kim „są”. Co oczywiste, w wielu przypadkach postawa obojętności jest z moralnego punktu widzenia lepsza niż tolerancja: lepiej, by ludzie byli obojętni na orientację seksualną swoich sąsiadów, niż żeby ją potępiali, a jednak tolerowali.

Jednak praktykowanie tolerancji to jedna rzecz, a pryncypialne racje stojace za tolerancją - to co innego. Często praktykowanie tolerancji nie jest ugruntowane w przekonaniu, że istnieją jakieś moralne racje na rzecz tolerowania odmiennych punktów widzenia i praktyk; że

8 B. Williams, Toleration: An Impossible Virtue? w: Toleration: An Elusive Virtue, red. D. Heyd, Princeton University Press, Princeton 1996, s. 19 . 
przyzwolenie na istnienie takich przekonań i praktyk, nawet pomimo naszej dla nich dezaprobaty, jest samo w sobie czymś dobrym lub moralnie pożądanym. Wiele działań, które mają pozór tolerancji pryncypialnej, jest w rzeczywistości niczym więcej niż pragmatycznym, czy też, jak moglibyśmy powiedzieć, „hobbesowskim” kompromisem: jedna grupa chętnie wypleniłaby przekonania i praktyki innej, ale daje za wygraną godząc się z faktem, iż nie uszłoby jej to na sucho - a w każdym razie nie bez ponoszenia nieakceptowalnego kosztu w postaci przysłowiowej „wojny wszystkich przeciwko wszystkim”. Dla kogoś z zewnątrz może się to wydawać tolerancją - jedna grupa zdaje się znosić drugą - jednak w żadnej mierze nie jest to egzemplifikacja tego, co Williams nazywa „cnotą" tolerancji (a co ja będę nazywał „tolerancją pryncypialną"), ponieważ racje stojące za znoszeniem danej grupy są czysto instrumentalne i egoistyczne i nie przyznają żadnej wagi względom moralnym. Jedna grupa znosi drugą wyłącznie ze względu na to, iż nie byłoby w jej własnym interesie ponoszenie kosztu koniecznego do wyplenienia przekonań i praktyk tej innej grupy.

Jednak nie tylko zwolennicy Hobbesa stwarzają pozory wierności zasadzie tolerancji. Według pewnej interpretacji pism Johna Locke’a9 jego główny, niewyznaniowy argument za tolerancją religijną polega na twierdzeniu, że represyjne mechanizmy państwa nie są w stanie spowodować faktycznej zmiany przekonań religijnych czy jakichkolwiek innych. Autentycznych, szczerze żywionych przekonań nie da się wpoić pod przymusem, jako że kształtują się one pod wpływem do-

${ }^{9}$ J. Waldron, Locke: Toleration and the Rationality of Persecution w: Justifying Toleration: Conceptual and Historical Perspectives, red. S. Mendus, Cambridge University Press, Cambridge 1988, s. 61-86. Interpretacja Waldrona nie jest pozbawiona kontrowersji; por. np. A. Tuckness, Locke's Main Argument for Toleration, w: Toleration and Its Limits, „Nomos" 48, red. Jeremy Waldron, Melissa S. Williams, New York University Press, New York 2008, s. 114-38. 
wodów i racjonalnych uzasadnień, a nie gróźb ${ }^{10}$. W rezultacie, powie zwolennik Locke'a, lepiej przyzwyczaić się do tolerancji w praktyce - nie dlatego, byśmy mieli jakiś pryncypialny czy moralny powód, by pozwolić heretykom głosić swoje poglądy, ale dlatego, że państwo nie posiada właściwych narzędzi do wyleczenia ich z ich herezji, do wpojenia im tzw. słusznych przekonań.

Locke, można śmiało powiedzieć, nie w pełni docenił stopień, w jakim państwa i - w społeczeństwach kapitalistycznych - podmioty prywatne są zdolne do użycia wyrafinowanych metod skutecznego wpajania przekonań, metod zarówno bardziej subtelnych, jak i bardziej efektywnych niż mógł sobie wyobrażać. Fakt, że historia dostarcza nam tak licznych przykładów społeczeństw, w których tyrania nielicznych nad większością była przez większość uznawana za stan rzeczy w zasadzie pożądany, jest wystarczającym dowodem na to, iż państwa są zdolne skutecznie wpajać poglądy, nawet te niebezpiecznie fałszywe. „Instrumentalny” argument Locke'a na rzecz zasady tolerancji nie może stanowić zbytniej pociechy dla jej obrońców, wziąwszy pod uwagę jego (zrozumiałe) niedocenienie złożoności psychologii i socjologii indoktrynacji.

Pryncypialną tolerancję pozorują jednakże nie tylko zwolennicy Hobbesa i Locke'a. Pewien wariant locke'owskiego argumentu instrumentalnego jest widoczny w powszechnym motywie amerykańskiej myśli politycznej - dobrze wyartykułowanym w słynnej obronie wolności słowa autorstwa Fredericka Schauera ${ }^{11}$ - zgodnie z którym rządowi nie można

${ }^{10}$ Locke nadaje specyficznie protestancki akcent temu epistemicznemu argumentowi, jako że wierzy on, iż zbawienie jest możliwe w yłą c z $\mathrm{ni}$ e za sprawą wolnego (tj. niewymuszonego) przyjęcia doktryny religijnej. Z tego protestanckiego punktu widzenia brak tolerancji nie miałby s e n s u , ponieważ i tak nie pozwoliłby osiągnąć żadnego znaczącego religijnego celu biorąc pod uwage wymogi niezbędne do zbawienia.

${ }_{11}$ F. Schauer, Free Speech: A Philosophical Enquiry, Cambridge University Press, Cambridge 1982. Podobne rozważania można znaleźć również w traktacie Johna Stuarta Milla $O$ wolności, przeł. A. Kurlandzka, 
u fać, że rozporządzać on będzie nietolerancją „właściwie”, tj. w odpowiednich przypadkach. Słowa moga krzywdzić w bardzo różny sposób, zauważa Schauer i niemal wszystkie uzasadnienia, dlaczego powinniśmy znosić te krzywdy - poczynając od „wolnego rynku idei” Johna Stuarta Milla, kończąc zaś na Alexandra Meiklejohna koncepcji wolności słowa jako zasadniczej dla demokratycznej władzy sprawowanej przez obywateli - sa podatne na takie czy inne zarzuty. Mimo to, powiada Schauer, istnieje powód, by domagać się tolerowania przez państwo wszelkiego typu wypowiedzi (nawet tych krzywdzących), bowiem nie ma żadnych podstaw by sądić, że państwo dokona słusznych wyborów co do tego, które wypowiedzi powinny być poddane regulacji. Schauer nazywa to „argumentem z rządowej niekompetencji” i pisze:

Wolność słowa opiera się w dużej mierze na braku zaufania wobec zdolności rządu do dokonywania koniecznych rozróżnień, braku zaufania do rządowych rozstrzygnięć co jest prawdą, a co fałszem, na dostrzeganiu omylności przywódców politycznych i nieco głębszym braku zaufania do władz w ogóle ${ }^{12}$.

Problemem nie jest zatem to, jak głosi argument Locke’a, że rządowi brakuje odpowiednich środków do realizacji celów wymagających wybiórczej nietolerancji, lecz raczej to, że rząd nie jest k o m petentny - tj. nie można na nim polegać - w kwestii użycia tychże środków we właściwych przypadkach. Być może tego rodzaju instrumentalny argument na rzecz państwowej tolerancji jest bardziej wiarygodny, jednakże niczym nie różni się od argumentu Locke’a jeśli chodzi o strukturę uzasadniania: nie odpowiada na pytanie dlacze-

w: tegoż, Utylitaryzm. O wolności, Wydawnictwo Naukowe PWN, Warszawa 2005 , rozdz. 4.

${ }^{12}$ F. Schauer, Free Speech..., s. 86. 
go, z moralnego punktu widzenia, nie powinniśmy rugować odmiennych przekonań i praktyk, zauważa jedynie, że mamy małe szanse by zrobić to (za pośrednictwem aparatu państwowego) właściwie.

Autentyczna „zasada tolerancji” znajduje zastosowanie w sytuacjach, w których jedna grupa (nazwijmy ją „dominującą”) w sposób aktywny potępia to, w co inna grupa (nazwijmy ją „mniejszościową”) wierzy bądź co robi; w których grupa dominująca dysponuje wystarczającymi środkami, by efektywnie i niezawodnie zmienić lub ukrócić przekonania lub praktyki grupy mniejszościowej, a mimo to przyznaje, że istnieją powody moralne bądź epistemiczne (tzn. związane $\mathrm{z}$ wiedzą lub prawda), by pozwolić grupie mniejszościowej na zachowanie swoich przekonań i praktyk. Jest to tolerancja „czysta” bądź „pryncypialna”13 i pytanie brzmi, czy istnieje tego typu powód, aby tolerować religię.

Moim głównym tematem będą pryncypialne podstawy tolerancji państwowej, w przeciwieństwie do tolerancji występującej w relacjach międzyludzkich, choć kwestie te są często zbliżone. Niektórzy współcześni „liberalni” filozofowie uważają, że właściwą postawą nowoczesnego państwa jest neutralność, a nie sugerująca dezaprobatę tolerancja. Ja jednak odrzucam pogląd, jakoby jakiekolwiek państwo mogło być prawdziwie neutralne w tym sensie; jak będę argumentował w rozdziale piątym, każde państwo reprezentuje i wciela w życie jakąś, jak to nazywam, „Wizję Dobra” - nawet jeśli większość zachodnich państw demokratycznych nie aprobuje już tak wyraźnie religijnej wizji. Państwo amerykańskie uznało nie tylko, że „wolność i równość wszystkich ludzi” są fundamentalnymi wartościami, lecz także, że każde dziecko musi uczyć się darwinowskiej teorii ewolucji drogą doboru na-

13 Piszę „czysta” bądź „pryncypialna”, ponieważ w takich przypadkach tolerancja nie jest motywowana pobudkami egoistycznymi - przynajmniej nie bezpośrednio. 
turalnego, choć nie musi „wiedzieć” niczego na temat biblijnej wizji stworzenia. Państwo amerykańskie nie jest w żadnym razie neutralne wobec związków wyznaniowych, które odrzucają „wolność i równość wszystkich ludzi”, nie mówiąc już o tych, które uznają, iż mit o stworzeniu stoi na równi z biologią i zasługuje na poświęcenie mu identycznej ilości czasu w szkołach publicznych. Tolerancja zachowuje więc $\mathrm{w}$ liberalnym państwie - podobnie jak na poziomie jednostkowym - walor cnoty. Nawet jeśli ktoś chce twierdzić, że państwo może aspirować do większej neutralności niż zakładam, to wciąż w sytuacjach, w których poszczególne mniejszości domagają się zwolnienia $\mathrm{z}$ ogólnie stosowanych praw ze względu na religijne bądź jakiekolwiek inne nakazy sumienia, nie żądają one wcale neutralności, tylko czegoś na kształt cnoty tolerancji. Domagają się mianowicie, aby państwo zawiesiło swoje dążenie do powszechnego dobra w imię tolerowania ( $\mathrm{tj}$. „znoszenia”) praktyk sumienia mniejszości swoich obywateli, które są niezgodne z tym dążeniem. Właśnie dlatego kluczowe pytanie tej książki brzmi: jakie są pryncypialne powody, by państwo zwolniło religijne nakazy sumienia z obowiązku podporządkowania się jego prawom? Ujmuję ten problem w taki właśnie sposób, ponieważ nawet jeśli z historycznego punktu widzenia zagadnienie tolerancji religijnej wynikało z konfliktów pomiędzy grupami religijnymi, to z punktu widzenia współczesności, przynajmniej w post-oświeceniowych państwach świeckich (pośród których być może nadal są Stany Zjednoczone), przedstawia się ono inaczej, a mianowicie: dlaczego w ogóle państwo powinno tolerować religię jako taką.

\section{Argumenty na rzecz tolerancji pryncypialnej}

Nim rozważymy tolerancję religijną w szczególności, warto przyjrzeć się ogólnej strukturze pryncypialnych argumentów na rzecz państwowej tolerancji różnic międzygrupowych. Lite- 
ratura na ten temat jest niezwykle obszerna, więc z konieczności będę w stanie rozważyć jedynie kilka wątków, które jednak, jak mniemam, dobrze ujmują wiodące stanowiska w tej debacie.

Możemy rozróżnić dwie szerokie klasy pryncypialnych argumentów na rzecz tolerancji, które dalej będę nazywał etycznymi i epistemicznymi (choć te drugie, ostatecznie, również opierają się na podstawach moralnych). Ściśle etyczne argumenty na rzecz tolerancji głoszą albo, że istnieje praw o do wolności przekonań i praktyk, które powinny być tolerowane; albo że tolerowanie tych przekonań i praktyk jest nieodzowne dla realizacji moralnie istotnych dóbr. Argumenty te dzielą się, jak można się spodziewać, na kantowskie i utylitarystyczne ${ }^{14}$.

Jako wzorcowy argument spośród kantowskich w szerokim sensie rozważmy teorię sprawiedliwości Rawlsa, zgodnie z którą tolerancja „wynika z zasady równej wolności”15, jednej z dwóch podstawowych zasad sprawiedliwości, które, jak twierdzi Rawls, racjonalne podmioty wybrałyby w położeniu, które nazywa on „sytuacją początkową" - tzn. w takim stanie rzeczy, w którym jednostki wybieraja podstawowe zasady sprawiedliwości rządzące ich społeczeństwami i w którym czynią to nie posiadając informacji na temat swego miejsca w społeczeństwie, które to informacje sprawiłby, że podejmowaliby decyzje stronnicze i samolubne. Jak ujmuje to Rawls:

(...) strony muszą wybrać zasady, które zapewniają integralność ich wolności religijnej i moralnej. Oczywiście nie

14 Ponieważ chcę się skupić ściśle na tolerancji, nie zamierzam zajmować tutaj stanowiska w kwestii względnych zalet pozycji kantowskich i utylitarystycznych, szczególnie że etyka i filozofia polityczna w ciaggu ostatnich dwustu lat nie poczyniły w tej mierze znaczących postępów.

15 J. Rawls, Teoria sprawiedliwości, przeł. M. Panufnik, J. Pasek, A. Romaniuk, Wydawnictwo Naukowe PWN, Warszawa 1994, s. 292 (wyd. II, 2009: s. 316). 
wiedzą one, jakie są ich przekonania religijne czy moralne, ani jaka jest konkretna treść ich zobowiązań moralnych czy religijnych, tak jak je rozumieją. (...) Dalej, strony nie wiedzą, jaka jest pozycja ich przekonań religijnych i moralnych w społeczeństwie, na przykład czy są one w większości czy w mniejszości. (...) jedyną zasadą, jaką mogą uznać osoby w sytuacji początkowej, jest zasada równej wolności sumienia. Nie mogą wystawić swej wolności na ryzyko przyzwalając na to, by dominujacca doktryna religijna lub moralna prześladowała czy tłumiła inne, gdy tego zapragnie. Nawet jeśli przyznamy (...), że jest najbardziej prawdopodobne, iż okaże się, że należy się do większości (jeśli jakaś większość istnieje), ryzykowanie w taki sposób dowodziłoby, że nie traktuje się swych religijnych czy moralnych przekonań poważnie bądź nie ceni się wysoko wolności sprawdzania swoich przekonań ${ }^{16}$.

Zauważmy, że nic w tym argumencie nie odnosi się wyłącznie do religii: jest to, jak wyraźnie zaznacza Rawls, argument na rzecz praw gwarantujacych „wolność sumienia”, która może oczywiście obejmować kwestie jednoznacznie religijne, ale nie jest do nich ograniczona ${ }^{17}$. Argument opiera się jedynie na

16 Tamże, s. 281-282 (wyd. II: s. 305).

17 Pomijam późniejszą rewizję stanowiska Rawlsa zawartą w: Political Liberalism (Columbia University Press, New York 1993) ponieważ zajmuje się ona kwestiami, które nie mają zastosowania do pryncypialnego argumentu tu rozwijanego, jako że zakładają istnienie „zazębiającego się konsensusu" co do zasad rządzących życiem politycznym, który, jak uważam, jest niemożliwy do osiągnięcia. W tej późniejszej pracy Rawls dochodzi do wniosku, że - jak ujmuje to Samuel Freeman - „żadna tradycyjna koncepcja etyczna ( $\mathrm{w}$ tym także sprawiedliwości jako bezstronności [tj. koncepcja Teorii sprawiedliwości]) nie może realnie aspirować do stania się powszechną podstawa pod najważniejsze zasady moralne i polityczne" (S. Freeman, The Burdens of Public Justification: Constructivism, Contractualism, and Publicity, „Politics, Philosophy and Economics" 6, 2007, s. 9). Ety c z ny wymiar Teorii sprawiedliwości jest teraz traktowany jako kolejna „całościowa” doktryna, która może zostać racjonalnie odrzucona przez członków pluralistycznego społeczeństwa zakładanego przez liberalizm, a tym samym nie spełnia standardów racjonalnego „powszechnego uzasadnienia”, jakiego społeczeństwo to wymaga. 
założeniu, że jednostki w „sytuacji początkowej” są świadome, iż będą miały pewne przeświadczenia na temat tego, jak mus z ą się zachować w określonych sytuacjach - przeświadczenia zakorzenione $\mathrm{w}$ racjach stanowiących o integralności całego ich życia.

Argumenty utylitarystyczne posiadają podobną cechę mianowicie, nie wyróżniają religii w żaden szczególny sposób spośród innych istotnych spraw sumienia. Argumenty te mają wiele różnych wariantów, jednak wszystkie łączy, w ten czy inny sposób, pewna centralna idea, wedle której ochrona wolności sumienia przed naruszeniami ze strony państwa maksymalizuje dobrostan jednostki, jakkolwiek należałoby go rozumieć ${ }^{18}$.

Dlaczego ochrona wolności sumienia miałaby się przyczyniać do dobrostanu jednostki? Wiele argumentów sprowadza się w gruncie rzeczy do prostej myśli: mianowicie możliwość wyboru w co wierzyć i jak żyć (w ramach pewnych ograniczeń, o których więcej wkrótce) pozwala wieść lepsze życie. I odwrotnie, otrzymywanie nakazów, w co należy wierzyć i jak ma się żyć, czyni życie gorszym. Określę tę prostą myśl mianem „argumentu z przestrzeni osobistej". Jest korzystne dla ludzkiego dobrostanu, głosi ów argument, by, w ramach pewnych ograniczeń, jednostki posia-

(Jest to jeden z powodów, dla których uznałem za istotne, by przyjrzeć się argumentom utylitarystów na rzecz podobnych wniosków.) Jak zauważyli krytycy liberalizmu politycznego (por. np.: Joseph Raz, Facing Diversity: The Case of Epistemic Abstinence, „Philosophy \& Public Affairs” 19, 1990, s. 3-46), zdaje się to być pomyleniem zagadnienia psychologii i socjologii polityki (co czyni ład polityczny uprawnionym w oczach jego obywateli?) z zagadnieniem, która koncepcja sprawiedliwości jest prawdziwa bądź uzasadniona - chyba że, rzecz jasna, ktoś uważa, że powszechna zgoda stanowi kryterium prawdziwości, z czym Rawls się nie zgadza i co tak czy inaczej wydaje się mało wiarygodne.

18 Dobrym, niedawnym przykładem jest T. Macklem, Independence of Mind, Oxford University Press, Oxford 2006. 
dały „przestrzeń osobistą”, w zakresie której mogą swobodnie podejmować decyzje, w co wierzyć i jak żyć.

Czy jest prawdą, że pozostawienie ludziom przestrzeni osobistej zwiększa ich dobrostan? A może wiele ludzi, możliwe nawet, że zdecydowana większość, jest nieszczęśliwa - tzn. wiedzie gorsze życie - właśnie dlatego, że podejmuje nierozsądne decyzje, w co wierzyć i jak żyć? Lub też dlatego, że, jako zakładnicy uwarunkowań społecznych i ekonomicznych, w ogóle nie podejmują żadnych prawdziwych decyzji, ciesząc się jedynie złudzeniem wyboru? Te antyliberalne myśli - dobrze znane czytelnikom Platona, Karola Marksa, Herberta Marcusego i wielu innych - cieszą się dziś niewielkim wzięciem w głównym nurcie anglojęzycznych teorii etycznych i politycznych, choć, jak mi się wydaje, nie dlatego, że zostały metodycznie obalone ${ }^{19}$. Na potrzeby mojego wywodu pozwolę sobie wziąć te wątpliwości w nawias i uznać argument z przestrzeni osobistej za przekonujący i tym samym stanowiący utylitarystyczną podstawę dla tolerancji. Zauważmy również, że stwarza on nieco pojemniejszy grunt dla wolności wyboru niż argument Rawlsa, który zdaje się być ograniczony jedynie do spraw sumienia (spraw, co do których, na przykład, istnieją silne racje stanowiące o integralności osobistej itd.).

W przeciwieństwie do argumentów etycznych na rzecz tolerancji, które właśnie omówiliśmy, argumenty epistemiczne pokazują, jak tolerancja przyczynia się do poznania. Najbardziej systematyczną artykulację tego typu argumentów znaleźć można w pismach Johna Stuarta Milla. Jak

${ }_{19}$ Przeprowadzona przez Michaela Rosena krytyka tezy Marksa o fałszywej świadomości stanowi wyjątek (por. M. Rosen, On Voluntary Servitude: False Consciousness and the Theory of Ideology, Harvard University Press, Cambridge, Mass. 1996). Nie uważam, by była to krytyka udana (por. B. Leiter, The Hermeneutics of Suspicion: Recovering Marx, Nietzsche, and Freud, w: The Future for Philosophy, red. tenże, Clarendon Press, Oxford 2004, zwłaszcza s. 84-87). 
twierdzi Mill ${ }^{20}$, tolerancja jest potrzebna, ponieważ (1) odkrywanie prawdy (czy też żywienie we właściwy sposób przekonania na temat tego, co jest prawdziwe) przyczynia się do powszechnej użyteczności i (2) prawdę można odkryć (lub być we właściwy sposób przekonanym o tym, co jest prawdziwe) jedynie w okolicznościach, w których dozwolone są różnorakie przekonania i praktyki. Pierwsza przesłanka w argumencie Milla na rzecz tolerancji ma, co dość oczywiste, charakter moralny: powinno nam zależeć na prawdzie (bądź byciu o niej przekonanym w sposób właściwy), ponieważ przyczynia się ona do ważnego z punktu widzenia moralności celu, jakim jest użyteczność. Friedrich Nietzsche - i nie tylko on - odrzucał tę przesłankę moralną: „prawda jest straszna”21, powiada, mając na myśli dokładnie to, że czasami znajomość prawdy nie sprzyja życiu, a przez to także użyteczności (choć sam Nietzsche, rzecz jasna, o użyteczność szczególnie się nie troszczył).

Wyłącznie druga przesłanka argumentu Milla, głosząca, że tolerowanie szerokiego spektrum przekonań sprzyja poznaniu prawdy, jest jednoznacznie epistemiczna. Zwróćmy uwagę, że „prawda”, o jaką chodzi Millowi, jest kwestią zarówno prawd o „faktach”, jak i prawd o „wartościach” w szczególności prawd o charakterze etycznym na temat najlepszych sposobów życia dostępnych istotom takim jak my. $\mathrm{Z}$ epistemicznego punktu widzenia zarówno prawdy o charakterze faktualnym, jak i etycznym mają pewne wspólne cechy. Po pierwsze, w odniesieniu do żadnej z nich nie jesteśmy uprawnieni do założenia własnej nieomylności: możemy być w błędzie, co stanowi wystarczający powód, by dopuszczać do głosu inne opinie, które mogą być prawdziwe. Po drugie, na-

${ }^{20}$ Por. J.S. Mill, $O$ wolności..., zwłaszcza rozdziały drugi i trzeci.

${ }^{21}$ F. Nietzsche, Ecce Homo. Jak się staje - kim się jest, przeł. L. Staff, Nakład Jakóba Mortkowicza, Warszawa - Kraków 1912, s. 115 (część czwarta, akapit pierwszy). 
wet zakładając, iż nasze przekonania są w pewnym stopniu prawdziwe, mamy większą szansę poznać całą prawdę, jeżeli skonfrontowani będziemy z odmiennymi poglądami, być może częściowo prawdziwymi pod innymi względami. W końcu, po trzecie, nawet jeżeli nasze obecne przekonania są w pełni prawdziwe, mamy większą szansę oprzeć je na właściwych racjach, zwiększając tym samym ich niezawodność, o ile musimy odpierać argumenty ludzi posiadających odmienne, nawet błędne, opinie. Z tych wszystkich epistemicznych powodów tolerowanie szerokiego zakresu różnorakich przekonań jest, zdaniem Milla, uzasadnione.

Prawdy etyczne jednakże - tj. prawdy na temat tego, jak powinniśmy żyć - dostarczają podstaw dla szerszego spektrum tolerancji, obejmującego nie tylko przekonania, lecz również $\mathrm{dzi}$ iłania. A to dlatego, że epistemiczne warunki odkrywania prawd etycznych wymagają od nas nie tylko konfrontacji z odmiennymi poglądami, lecz także, jak ujmuje to Mill, „praktycznego dowodu wartości różnych sposobów życia” poprzez, jak je nazywa, „eksperymenty życiowe”22. Innymi słowy, by dowiedzieć się, jak naprawdę powinniśmy żyć, nie wystarczy wysłuchać odmiennych opinii na ten temat; potrzebne są także empiryczne świadectwa w postaci żywotów faktycznie przeżytych według rozmaitych zasad. Na przykład jedynie dzięki obserwacji (a jeszcze lepiej, dzięki doświadczeniu) życia zadowolonej świni i niezadowolonego Sokratesa (jak w słynnym przykładzie Milla), możemy posiąść wiedzę o tym, że to drugie jest lepsze, tzn., że w jego skład wchodzą przyjemności wyższego rzędu.

Zanim przyjrzymy się uważniej szczególnemu przypadkowi tolerancji religijnej, powinniśmy zwrócić uwagę na jeszcze jedną cechę pryncypialnych argumentów na rzecz tolerancji:

22 J.S. Mill, $O$ wolności..., s. 156 (ponieważ istniejący polski przekład jest w cytowanych fragmentach czasem niezręczny bądź nieprecyzyjny, został nieznacznie zmodyfikowany). 
tę mianowicie, że wszystkie one uznają, iż zakres tolerancji powinien mieć pewne ograniczenia ${ }^{23}$. Nawet jeżeli istnieje prawo do wolności sumienia, które wymaga od państwa tolerowania różnorakich przekonań i praktyk, jak utrzymuje Rawls i nawet jeśli tolerancja przyczynia się do powszechnej użyteczności czy szczęśliwości - bądź ułatwia zdobycie wiedzy przyczyniającej się do powszechnej użyteczności - jak głoszą argumenty utylitarystyczne, wciąż wskazać można pewne granice państwowej tolerancji wobec działań podyktowanych wyrokami sumienia.

Dla zwolenników Rawlsa „ograniczenie wolności jest usprawiedliwione jedynie wtedy, gdy jest konieczne ze względu na samą wolność, by zapobiec jakiemuś jeszcze gorszemu zamachowi na wolność”, więc „wolność sumienia może być ograniczana tylko wtedy, gdy można zasadnie przypuszczać, że zaniechanie tego zniszczy porządek publiczny, który władza państwowa ma utrzymywać”. „Przypuszczenie to”, pisze dalej Rawls, „musi być oparte na świadectwach i sposobach rozumowania, które są do przyjęcia dla wszystkich"24. Dla utylitarystów, dla odmiany, granice tolerancji są zazwyczaj określane przez taką czy inną wersję słynnej Zasady Krzywdy Milla, zgodnie z którą ,jedynym celem, dla osiągnięcia którego prawomocne jest użycie siły wobec członka cywilizowanej społeczności wbrew jego woli, jest to, aby zapobiec krzywdzie innych"25.

W obu teoretycznych ujęciach granice tolerancji wyznaczane są przez interesy wolności bądź dobrostanu pozostałych członków wspólnoty; kryteria te ograniczają przede wszystkim tolerancję praktyk czy d ziałań, a nie przekonań, z których one wynikają. Zarówno według poglądu Rawlsa jak i Milla

${ }^{23}$ Rozmowa z Rossem Harrisonem, którą przeprowadziłem na wczesnym etapie pracy, pomogła mi w doprecyzowaniu moich rozważań na ten temat.

${ }^{24}$ J. Rawls, Teoria sprawiedliwości, s. 293 i 291 (wyd. II: s. 316 i 314).

25 J.S. Mill, $O$ wolności..., s. 102 (przekład zmieniony; por. przypis 22). 
państwo nadal będzie musiało tolerować, jak się zdaje, przekonania pewnej grupy religijnej mówiące, że wyznawcy wszelkich innych religii są heretykami skazanymi na potępienie; jednakże państwo nie musi tolerować pragnienia tejże grupy do działania na podstawie tych przekonań, np. zabijania niemowląt rzeczonych heretyków nim ich dusze zostaną spaczone herezją i w konsekwencji skazane na wieczne potępienie.

Tego typu przypadki są, rzecz jasna, łatwe do rozstrzygania w kontekście dowolnych poglądów na tolerancję i jej granice. $\mathrm{O}$ wiele trudniej osądzić dwa inne rodzaje sytuacji: po pierwsze, te dotyczące wyrażania przekonań, które mogą choć nie muszą - prowadzić do działań naruszających wolność czy w inny sposób powodujących wyrządzenie bezprawnej krzywdy; i po drugie, te dotyczące praktyk bądź działań, które również mogą - choć nie muszą - prowadzić do analogicznych skutków.

Mill ma, oczywiście, na myśli ten pierwszy rodzaj, gdy pisze:

(...) nawet opinie tracą swoją nietykalność, gdy są wyrażane w takich okolicznościach, że stają się zachętą do szkodliwego czynu. Opinia, że handlarze zbożem są winni tego, iż biedacy głodują lub że własność prywatna jest kradzieżą, nie powinna być cenzurowana, gdy jest tylko ogłaszana drukiem, lecz może zasługiwać na karę, gdy się ją wypowiada ustnie wobec podnieconego tłumu zgromadzonego przed domem handlarza zbożem $(. . .)^{26}$.

Ta sama myśl została skodyfikowana w amerykańskim prawie konstytucyjnym za pomocą doktryny głoszącej, że wypowiedzi stanowiące tzw. „wyraźne i bezpośrednie zagrożenie” (clear and present danger $)^{27}$ mogą być cenzurowane przez

${ }^{26}$ Tamże, s. 155 (przekład zmieniony).

${ }^{27}$ Wymaganie „wyraźnego i bezpośredniego zagrożenia” bierze się z wyroku Sądu Najwyższego Stanów Zjednoczonych w sprawie Schenck v. United States („United States Reports” t. 249, 1919, s. 47-53). Zastą- 
państwo. Podejście takie zakłada, że wolno utrzymywać i wyrażać dowolne przekonania, chyba że istnieje ścisły związek przyczynowo-skutkowy pomiędzy wyrażeniem danego przekonania a zakazanymi działaniami. Poglądy Rawlsa zdają się sprowadzać do tego samego, choć sam Rawls wyraża je za pomocą odmiennej metaforyki: zagrożenie wolności musi być „w sposób pewny stwierdzone we wspólnym doświadczeniu"28. Sformułowanie Rawlsa nie zawiera wymagania, by wyrządzona w rezultacie krzywda była tak niez wło c z n a czy bezpośrednia jak w przykładach prezentowanych przez Milla lub w doktrynie amerykańskiego prawa konstytucyjnego. Z punktu widzenia Rawlsa wystarczy, by zajście związku przyczynowo-skutkowego między wyrażeniem poglądu a pogwałceniem wolności było „w sposób pewny stwierdzone". Z pewnością jednak kryteria pe w ne go st wier d z e nia tego związku mogą zostać spełnione wyłącznie w tych samych przypadkach niezwłocznego bądź bezpośredniego szkodliwego działania, jakie rozważał Mill, z którego to powodu można uznać, iż oba stanowiska sprowadzają się do tego samego $^{29}$.

Drugi rodzaj przypadków przedstawia podobny problem: istnieją praktyki oparte na przekonaniach, które wydają się z asługiwać na tolerancję (na podstawie poglądu zarówno Milla, jak i Rawlsa), co do których możemy mieć wątpliwości, czy pozostają w związku przyczynowym z jakąś szkodą w sposób spełniający obowiązujące standardy dowodowe. Przypadek ten dobrze ilustruje kanadyjska sprawa Multani

piono je w ramach doktryny prawnej koncepcją „bezpośredniego niebezpieczeństwa złamania prawa" (imminent lawless action) w wyroku w sprawie Brandenburg v. Ohio („United States Reports” t. 395, 1969, s. 444-456).

${ }^{28}$ J. Rawls, Teoria sprawiedliwości, s. 294 (wyd. II: s. 318).

${ }^{29}$ W książce Political Liberalism, s. 348-356, Rawls zresztą otwarcie aprobuje warunek „wyraźnego i bezpośredniego zagrożenia”. 
v. Commission scolaire Marguerite-Bourgeoys ${ }^{30}$ z 2006 roku dotycząca prawa sikhów do noszenia kirpanu (ceremonialnego noża), jak wymaga tego ich religia - również w szkołach. Strona sprzeciwiająca się tej religijnej praktyce argumentowała, że stwarza ona zbyt wielkie zagrożenie wyrządzenia krzywdy, co znajduje zresztą odzwierciedlenie w powszechnym zakazie wnoszenia broni do szkół; druga strona odpowiadała, że prawdopodobieństwo wyrządzenia krzywdy jest bardzo niskie, czego dowodem jest fakt, że nieznane są żadne udokumentowane przypadki użycia kirpanu w charakterze broni. Najwyższy Sąd Kanady rozstrzygnął, rzecz jasna, na rzecz tolerowania praktyki noszenia kirpanu, zważywszy na wagę, jaką przywiązują do niej wyznawcy, domniemane niewielkie ryzyko wyrządzenia krzywdy i specjalne miejsce, jakim cieszy się wielokulturowość w Kanadyjskiej Karcie Praw i Wolności.

Przełożyli Dominik Janas i Maciej Jemioł

\section{Bibliografia}

Freeman, Samuel, The Burdens of Public Justification: Constructivism, Contractualism, and Publicity, „Politics, Philosophy and Economics" 6, 2007, s. 5-43.

Konstytucja Kanady, przeł. Joachim Osiński i Izabela Zawiślińska, Wydawnictwo Sejmowe, Warszawa 1998.

Konstytucja Niemiec, przeł. Bogusław Banaszak i Agnieszka Malicka, Wydawnictwo Sejmowe, Warszawa 2008.

Konstytucja Stanów Zjednoczonych Ameryki, przeł. Andrzej Pułło,

Wydawnictwo Sejmowe, Warszawa 2002.

30 Wyrok w sprawie Multani v. Commission scolaire Marguerite-Bourgeoys, „Canada Supreme Court Reports” t. 6, 2006, s. 256-325. 
Laycock, Douglas, Regulatory Exemptions of Religious Behavior and the Original Understanding of the Establishment Clause, „Notre Dame Law Review" 81, 2006, s. 1793-1842.

Laycock, Douglas, Religious Liberty as Liberty, „Journal of Contemporary Legal Issues" 7, 1996, s. 313-356.

Leiter, Brian, The Hermeneutics of Suspicion: Recovering Marx, Nietzsche, and Freud w: The Future for Philosophy, red. Brian Leiter, Clarendon Press, Oxford 2004, s. 74-105.

Leiter, Brian, Why Tolerate Religion?, Princeton University Press, Princeton 2013.

Macklem, Timothy, Independence of Mind, Oxford University Press, Oxford 2006.

Mill, John Stuart, On Liberty, John W. Parker and Son, London 1859.

Mill, John Stuart, O wolności, przeł. Amelia Kurlandzka, w: tegoż, Utylitaryzm. O wolności, przeł. Amelia Kurlandzka, Maria Ossowska, Wydawnictwo Naukowe PWN, Warszawa 2005.

Nietzsche, Friedrich, Ecce Homo. Jak się staje - kim się jest, przeł. Leopold Staff, Nakład Jakóba Mortkowicza, Warszawa - Kraków 1912.

Powszechna Deklaracja Praw Człowieka, rezolucja Zgromadzenia Ogólnego ONZ 217, 10.12.1948.

Rawls, John, Political Liberalism, Columbia University Press, New York 1993.

Rawls, John, Liberalizm polityczny, przeł. Adam Romaniuk, Wydawnictwo Naukowe PWN, Warszawa 1998.

Rawls, John, A Theory of Justice, Harvard University Press, Cambridge, Mass. 1971.

Rawls, John, Teoria sprawiedliwości, przeł. Maciej Panufnik, Jarosław Pasek, Adam Romaniuk, Wydawnictwo Naukowe PWN, Warszawa 1994. Wyd. II, uzupełnione: 2009.

Raz, Joseph, Facing Diversity: The Case of Epistemic Abstinence, „Philosophy \& Public Affairs” 19, 1990, s. 3-46.

Rosen, Michael, On Voluntary Servitude: False Consciousness and the Theory of Ideology, Harvard University Press, Cambridge, Mass. 1996.

Schauer, Frederick, Free Speech: A Philosophical Enquiry, Cambridge University Press, Cambridge 1982.

Tuckness, Alex, Locke's Main Argument for Toleration, w: Toleration and Its Limits, „Nomos” 48, red. Jeremy Waldron, Me- 
lissa S. Williams, New York University Press, New York 2008, s. $114-38$.

Waldron, Jeremy, Locke: Toleration and the Rationality of Persecution w: Justifying Toleration: Conceptual and Historical Perspectives, red. Susan Mendus, Cambridge University Press, Cambridge 1988, s. 61-86.

Williams, Bernard, Toleration: An Impossible Virtue? w: Toleration: An Elusive Virtue, red. David Heyd, Princeton University Press, Princeton 1996, s. 18-27.

Prof. Brian Leiter

Center for Law, Philosophy \& Human Values

University of Chicago

bleiter@uchicago.edu 
